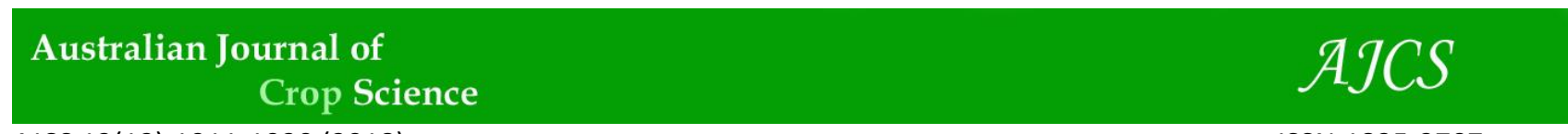

AJCS 12(12):1911-1920 (2018)

ISSN:1835-2707

doi: 10.21475/ajcs.18.12.12.p1230

\title{
Breeding for anthracnose (Colletotrichum sublineolum Henn.) resistance in sorghum: challenges and opportunities
}

\author{
Girma Mengistu* ${ }^{1,2}$, Hussein Shimelis ${ }^{1}$, Mark Laing ${ }^{1}$ and Dagnachew Lule $^{2}$ \\ ${ }^{1}$ University of KwaZulu-Natal, School of Agricultural, Earth and Environmental Sciences, Private Bag X01, Scottsville \\ 3209, Pietermaritzburg, South Africa \\ ${ }^{2}$ Oromia Agricultural Research Institute, P.O. Box 81265, Addis Ababa, Ethiopia
}

*Corresponding author: germame2004@gmail.com

\begin{abstract}
Sorghum [Sorghum bicolor (L.) Moench] is an important cereal crop grown for its diverse uses. Global sorghum production and productivity is affected by various stresses notably by biotic factors such as diseases, weeds and insect pests. Anthracnose caused by the fungal pathogen Colletotrichum sublineolum Henn. (formerly known as C. graminicola [Ces.] G.W. Wilson), grain mold, leaf blight, rust and smut are among the most import diseases of sorghum, while stem borer, shoot fly, termites and birds are notable pests of the crop. Sorghum anthracnose occurs in epidemic proportions under high temperature and humidity conditions causing yield losses reaching up to $67 \%$ in susceptible varieties. Sorghum shows considerable genetic variation. A large number of landraces are exploited in breeding for disease resistance and better agronomic performance. This review presents literature on breeding sorghum for anthracnose resistance and associated challenges and opportunities. Information presented in this paper may guide future breeding of sorghum varieties incorporating farmer needs and preferences.
\end{abstract}

Keywords: constraints, inheritance, microsatellites, resistance breeding, Sorghum bicolor.

Abbreviations: AFLPs_amplified fragment length polymorphisms, RAPD_randomly amplified polymorphic DNA, QTL_quantitative trait loci, SSRs simple sequence repeats, RFLPs restriction fragment length polymorphisms, SNPs single nucleotide polymorphisms.

\section{Introduction}

Sorghum [Sorghum bicolor (L.) Moench] is a C4 cereal crop belonging to the family Gramineae. It is relatively tolerant to harsh growing conditions with best adaptation under drought-prone and the semi-arid tropical regions of the world (Poehlman and Sleper 1995; Burrell et al., 2015; Ng'uni et al., 2011). Sorghum is naturally self-pollinating and a short-day crop (Doggett 1988). It shows variable degree of spontaneous cross-pollination, in some cases, reaching up to $30 \%$ depending on genotype, environment and genotype by environment interaction (Poehlman and Sleper 1995). The annual wild and domesticated sorghum species are diploids $(2 \mathrm{n}=2 \mathrm{x}=20)$ which are of tropical origin. It is widely adapted to regions lying between $40^{\circ} \mathrm{N}$ and $40^{\circ} \mathrm{S}$ of the equator (Doggett 1988). Sorghum is cultivated both in tropical and temperate climates for multiple uses such as for food, feed and brewery (Dahlberg et al., 2011).

The genus Sorghum consists of three widely known species S. halapense, S. propinquum and S. bicolor (Sun et al., 1994; Berenji and Dahlberg 2004). Sorghum bicolor is the cultivated species (Smith and Frederiksen 2000; Berenji and Dahlberg 2004) Sorghum bicolor comprises three subsspecies; S. bicolor subsp. bicolor, S. bicolor subsp. drummondii, and $S$. bicolor subsp. verticilliflorum (Berenji and Dahlberg 2004). Sorghum bicolor has the following five basic races: bicolor, guinea, caudatum, durra, and kafir (Harlan and De Wet 1972; Harlan and Stemler 1976; Doggett 1991; Smith and Frederiksen 2000). The races guinea and caudatum are predominantly cultivated in west and east Africa extending to Tanzania, Malawi, eastern Sudan and Uganda. Durra is the dominant race widely cultivated in India, Ethiopia, Sudan and Egypt, while Kafir is widely grown in eastern and southern Africa including in South Africa (Mann et al., 1983; Doggett 1991).

Ethiopia is believed to be the center of origin and diversity of sorghum due to the presence of diverse genetic pool and wild sorghum types (De Wet and Huckabay 1967; Doggett 1988; Smith and Frederiksen 2000). In the country, wild types of sorghum are prevalent. The four sorghum races are domesticated in Ethiopia except kafir (Mann et al., 1983; Doggett 1991). Sorghum genetic resources from Ethiopia have been widely used globally in various breeding programs (Doggett 1991; Smith and Frederiksen 2000).

Sorghum production and productivity is affected by biotic factors such as diseases, weeds and insect pests worldwide. Anthracnose caused by the fungal pathogen Colletotrichum sublineolum (Henn.) (formerly known as C. graminicola [Ces.] G.W. Wilson), grain mold, leaf blight, rust and smut are among the diseases, while stem borer, shoot fly, 
termites and birds are important pests of sorghum. Damage of sorghum anthracnose is pronounced under high temperature and humidity conditions causing yield losses reaching up to $67 \%$. Therefore, this review paper highlights breeding sorghum for anthracnose resistance and associated challenges and opportunities. The review summarized relevant information that may guide future breeding of sorghum varieties with anthracnose resistance incorporating farmer's needs and preferences.

\section{Global sorghum production}

Globally, sorghum is the most important economic crop in area of production next to wheat (Triticum spp.), rice (Oryza spp.), maize (Zea mays), and barley (Horedum vulgare) (FAO 2014). In sub-Saharan Africa, sorghum remains the third important cereal crop after maize and rice accounting about $22 \%$ of the cereal production area (FAO 2014). Ethiopia is the sixth largest sorghum producer next to USA, Mexico, Nigeria, Sudan and India (FAO 2014). During 2014 the highest sorghum productivity was recorded by France $(6.33 \mathrm{t}$ ha ${ }^{-1}$ ) followed by Egypt ( $5.42 \mathrm{t} \mathrm{ha}^{-1}$ ) (Fig 1 ).

In Ethiopia sorghum is the third largest cereal crop in area coverage and total production preceded by tef and maize. In the country sorghum is produced by 5 million smallholder farmers with an estimated total grain production of 4.34 million tonnes from an estimated area of 1.8 million hectares of land. This provides a national average grain yield of around $2.37 \mathrm{t} \mathrm{ha}^{-1}$ (CSA 2014; FAO 2014) (Fig 2). Sorghum covers $14.85 \%$ of the total area allocated to grain crop production (cereals, pulses, and oil crops) and $18.6 \%$ of the area covered by cereals in Ethiopia (CSA 2014).

There is an increasing trend of area allotment for sorghum production in Ethiopia. Besides, its productivity increased during the last 20 years due to considerable use of agricultural inputs (Fig 2). For instance, the area coverage, total production and yield of sorghum increased by 9.37 , 13.33 and $3.62 \%$, respectively during 2013 to 2014 (FAO 2014). The crop is highly valued especially in the drier environments of the country owing to its considerable drought-tolerance. Sorghum is recognized as food security crop in Ethiopia. Since recent years, the crop is considered as a strategic food security crop by the government and thus due emphasis is given to the genetic improvement and technology development of the crop to boost its productivity under the small-scale farming systems. However, several constraints are hindering sorghum production and productivity in the country and globally.

\section{Existing opportunities for sorghum production improvement}

\section{Versatile uses and market opportunities}

Soghum is grown for food, feed, fiber and biofuels (Paterson et al., 2009). Sorghum grain and fresh or dry biomass have diverse uses and market opportunities (McGuire 2008). About 500 million people in more than 30 countries living in arid and semi-arid tropics depeond on sorghum as a staple food (Dahlberg et al., 2011; Kumar et al., 2011). Sorghum grain is processed into flour to prepare fermented and unfermented breads, porridges, couscous, and snacks.
Malting sorghum is a valuable raw material to prepare alcoholic and non-alcoholic beverages (Abdi et al., 2002; Adugna 2014). (Dahlberg et al., 2011). Sorghum is second prefered crop next to tef (Eragrostis tef [Zucc.] Trotter) for preparing 'injera', a staple food in Ethiopia (Ayana and Bekele 2000).

\section{Adaptation to grow in divrse agro-ecologies}

Sorghum adapats to grow in divese agro-ecologies including in dry lowlands, intermidate and high altitudes (Doggett 1991). Sorghum is tolerant to heat and drought stress making it an ideal crop under limited rainfall and high temprature conditions in arid and semi-arid regions (Sharma et al., 2012; Billot et al., 2013) .

\section{Genetic variation of sorghum for variety design and deployment}

A total of 41,000 landraces and cultivars of sorghum are collected and conserved in the USA (Dahlberg et al., 2011). Most accessions were sourced from Ethiopia and Sudan which are the center of origin and diversity of sorghum (Vavilov 1951). More than 8000 indigenous sorghum accessions collected from different parts of Ethiopia are conserved at the Ethiopian Institute of Biodiversity Center (Mekbib 2008).

\section{Sorghum production constraints}

Production and productivity of sorghum is affected by both biotic (diseases, insect pests, and weeds) and abiotic (nutrient deficiency, aluminium toxicity, drought, high salinity, water logging and temperature stress) constraints (Tari et al., 2013). Important sorghum diseases include anthracnose, grain mold, leaf blight, rust and smut. Insect pests (stem borer, weevils, shoot fly, termites and birds) and the parasitic weed, Striga, are important biotic constraints of the crop (Ekeleme et al., 2011).

\section{Abiotic and biotic stresses affecting sorghum production and productivity}

Sorghum is a relatively drought tolerant crop and adapts to grow under marginal growing conditions (Berenji and Dahlberg 2004). However, the crop faces severe postflowering drought stress leading to substantial crop or yield losses. Moisture stress at early vegetative growth stage resulted sorghum yield reduction varying from $50 \%$ to $60 \%$. The largest yield reduction in sorghum was recorded reaching up to $87 \%$ when moisture stress occurred during booting and anthesis (Craufurd and Peacock 1993). Sorghum has a relatively better adaptation and yield stability under drought stress where other crops such as maize, wheat and rice fail under the same stress level (Berenji and Dahlberg 2004).

Sorghum production is also affected by soil nutrient deficiency and lower rate of inorganic fertilizer application (Doggett 1991). Most sorghum farmers in sub-Saharan Africa do not use inorganic fertilizers. In these farming systems the crop suffers nutrient deficiency resulting low yield levels than the attainable productivity of the crop. 


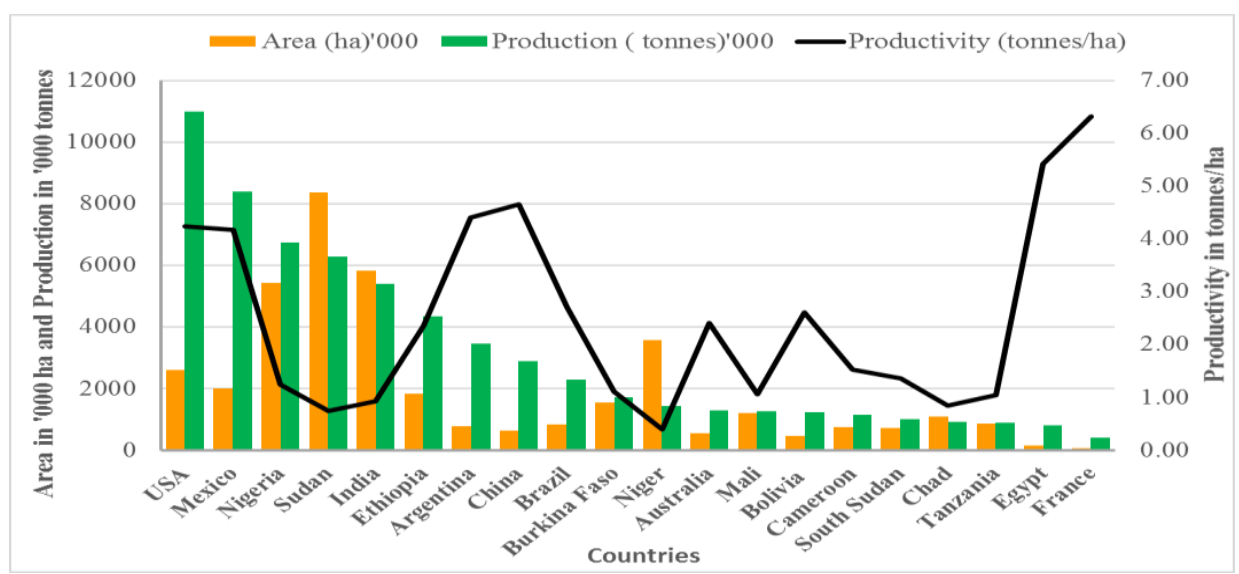

Fig 1. Sorghum cultivated area, production and yield in some countries of the world in 2014 (FAO 2014).

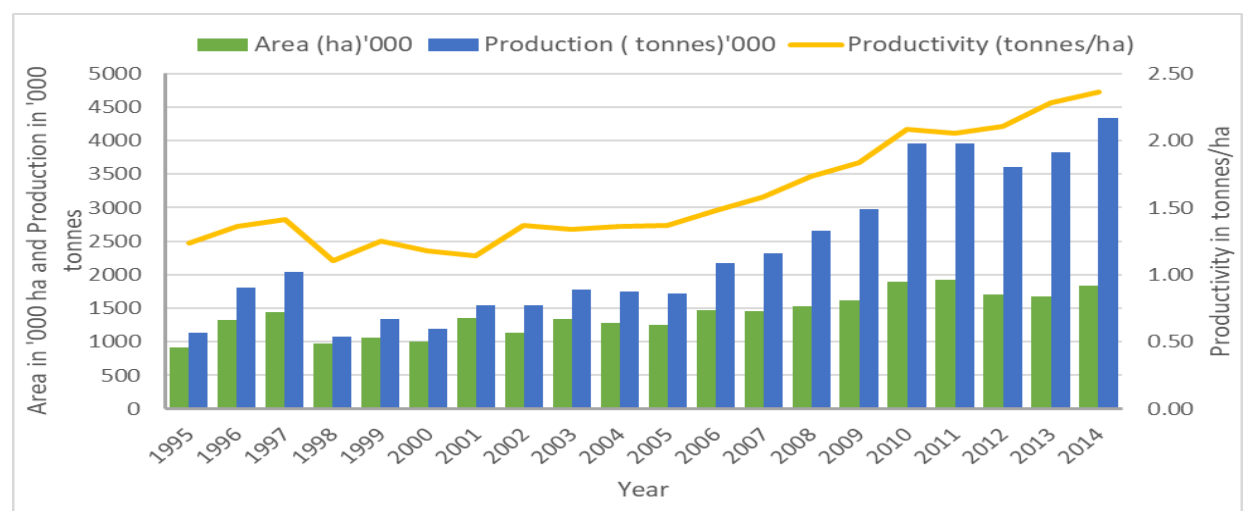

Fig 2. Trends of sorghum cultivated area, production and yield in Ethiopia during 1995-2014 (FAO 2014).

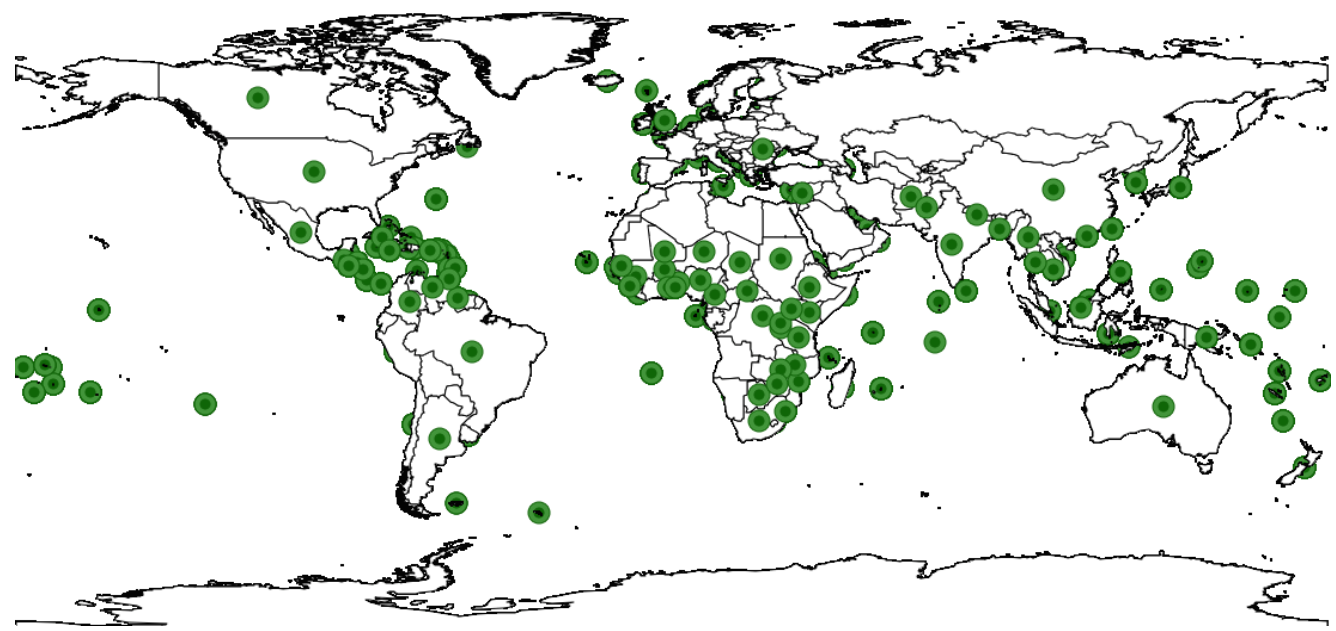

Fig 3. Sorghum anthracnose (Colletotrichum sublineolum) global distribution (CABI, 2017).

The biotic stress that hampers sorghum production broadly includes diseases, insect pests and weeds. These factors play greater role in yield reduction reaching approximately to $40 \%$ in susceptible varieties (Repellin et al., 2001).

\section{Major diseases of sorghum}

The major diseases of sorghum include anthracnose, leaf blight, rust, smut, mold and downy mildew. Anthracnose disease of sorghum is caused by Colletotrichum sublineolum Hann. Kabát et Bub. (syn. C. graminicola (Ces.) G.W. Wils.).
Thomas et al. (1996) reported that the disease resulted in yield reduction of $67 \%$ on susceptible cultivars. Leaf blight disease is caused by Exserohilum turcicum (Pass) Leonard and Suggs. Leaf blight infection occurs before flowering leading to yield loss reaching up to $50 \%$. When leaf blight appears late, yield loss can be minimal (Doggett 1988; Ngugi et al., 2000). Rust (Puccinia purpurea Cooke) is prevalent in most sorghum producing areas affecting grain yield and forage quality (Hulluka and Esele 1992). Other diseases such as head smut (Sporisorium reilianum) and downy mildew 
(Peronosclerospora sorghi) are important disease of sorghum (Gowda et al., 1995; Gwary et al., 2007).

\section{Insect pests of sorghum}

Sorghum shoot fly, Atherigona soccata, the lepidopterous stem borers, Chilo partellus, Busseola fusca and termites are important insect pests affecting sorghum production (Wortmann et al., 2009). Birds cause significant yield loss in sorghum fields (Davies 1982; Wortmann et al., 2009).

\section{Weeds}

Striga (Striga hermonthica) is a parasitic weed of sorghum and other cereal crops. Striga remains the first parasitic weed affecting sorghum production globally including Ethiopia (Haussmann et al., 2000; Vissoh et al., 2004; Gebretsadik et al., 2014). Other weed species such as Commelina benghalensis, Cyperus, Digitaria horizontalis and Ipomoea eriocarpa are major constraints to sorghum production (Vissoh et al., 2004).

Among the biotic constraints sorghum anthracnose disease is the major impediment to sorghum production and productivity. Therefore, there is a need for integrated disease control in sorghum production. The following sections provide a detail account on anthracnose disease, its economic importance, disease symptoms and control options including sorghum anthracnose resistance breeding.

\section{Economic importance of anthracnose disease}

Sorghum anthracnose is one of the most important diseases which cause significant yield and quality losses (Sharma et al., 2012; Tesso et al., 2012). It was believed that anthracnose was caused by $C$. graminicola affecting both sorghum and maize. However, recent reports account that the fungi affecting the two crops is different. Colletotrichum graminicola is identified to be a fungal pathogen causing anthracnose of maize ( $Z$. mays), while $C$. sublineola causes anthracnose disease of sorghum (Crouch and Beirn 2009). Anthracnose disease is observed in all sorghum growing areas of the world (Burrell et al., 2015; Costa et al., 2015; Resende et al., 2015; Patil et al., 2017) (Figure 3). The disease was first observed in Togo in the west Africa during 1902 (Thakur and Mathur 2000). The effects of sorghum anthracnose disease are pronounced in warmer areas where temperatures and relative humidity are the highest (Thakur and Mathur 2000; Mathur 2002; Marley et al., 2005; Mehta et al., 2005; Crouch and Beirn 2009; Burrell et al., 2015; Patil et al., 2017). Anthracnose disease development occurs on susceptible sorghum host and conducive weather conditions (Ali and Warren 1987; Neya and Le Normand 1998; Marley et al., 2001b; Erpelding and Prom 2004; Patil et al., 2017).

Anthracnose affects grain yield and yield components directly or indirectly. It affects directly 100 seed weight, seed density and exacerbate early abortion of seeds. On the other hand, premature drying and defoliation of leaves due to foliar anthracnose are indirect causes that reduced sorghum grain yield (Mathur 2002). In Mali, anthracnose caused yield loss of 18 to $36 \%$ on susceptible cultivars (Erpelding and Prom 2004). Other authors indicated that anthracnose resulted in $30-50 \%$ or greater yield and fodder losses in susceptible sorghum varieties under severe disease condition (Harris et al., 1964; Thomas et al., 1996; Mathur 2002; Marley et al., 2005; Tesso et al., 2012). Typically, sorghum anthracnose affects all parts of the plant including leaf, stem, panicle and grain (Erpelding and Prom 2004; Crouch and Beirn 2009). However, its effect is pronounced more on the leaf leading to a considerable reduction in photosynthesis and hence leading to reduced grain yield (Casela et al., 2001; Mathur 2002; Mehta et al., 2005; Crouch and Beirn 2009). It was also reported that anthracnose yield loss associated to stalk-rot leading to logging of sorghum plants (Harris et al., 1964).

\section{Symptoms of anthracnose disease}

Anthracnose disease symptoms are observed on all above ground parts of sorghum plant but it is most conspicuous on the leaf. The typical symptoms of sorghum anthracnose disease are leaf blight and stem rot (Felderhoff et al., 2016). It was reported that foliar infection of anthracnose disease occurred at any time of plant growth, however, symptoms are detected 40 days after emergence (Erpelding and Prom 2004). Anthracnose disease symptoms are observed as small circular to elliptical $(<5 \mathrm{~mm})$ spots or elongated red lesions with tan centers on susceptible sorghum cultivars. The fungus sporulates and fruiting bodies (acervuli) are observed as black spots in the center of the lesions and coalescence resulting leaf senescence (Erpelding and Prom 2004; Crouch and Beirn 2009).

\section{Survival mechanisms of sorghum anthracnose}

Colletotrichum sublineolum pathogen overwinters in the soil through different mechanisms. The fungus is harbored in plant residues as mycelium, acervuli, melanized hyphopodia, sclerotia and microsclerotia infected seeds of sorghum. Johnson grass is an alternative host of the pathogen. The pathogen survives in sorghum seed for 2.5 years at room temperatures (Crouch and Beirn 2009).

\section{Management of anthracnose disease in sorghum}

Anthracnose can be controlled using different options including fungicides, cultural practices such as weed and residue management, planting disease free seeds and crop rotation and host resistance (Mathur 2002; Erpelding and Prom 2004; Chala et al., 2010; Silva et al., 2015). In west and central Africa, proper crop residue management assisted in minimizing anthracnose disease (Marley et al., 2005).

Different seed treatment fungicides such as Apron-plus (a mixture of methalaxyl, carboxin and furathiocarp) and foliar fungicides such as carbendazin and maneb and mancozeb applications controlled sorghum anthracnose in Nigeria (Akpa et al., 1992). However, this method is not environmentally friendly and it is not economically feasible for small-scale farmers. The most economic and environmentally friendly option to controlling anthracnose is the use of resistant sorghum varieties (Erpelding and Prom 2004; Singh et al., 2006b; Tesso et al., 2012; Li et al., 2013).

\section{Breeding sorghum for host resistance}

Breeding sorghum for anthracnose resistance is the most sustainable, economic and environmentally friendly option 
to control anthracnose disease (Marley et al., 2005; Singh et al., 2006b; Chala et al., 2010; Li et al., 2013; Cuevas et al., 2014). There are numerous physiological races of anthracnose pathogen (Figueiredo et al., 2006; Patil et al., 2017). Virulent races are reported to be the main causes of loss of vertical resistance in sorghum (Mathur 2002; Thakur 2007). According to Buiate et al. (2010) anthracnose disease is conditioned by both vertical and horizontal resistance. Vertical resistance was conditioned by complete, incomplete dominance or recessive alleles. This form of resistance is reported to be less durable (Buiate et al., 2010). Recessive alleles controlling sorghum anthracnose disease were reported (Boora et al., 1998; Mehta et al., 2005; Singh et al., 2006a) conferring effective resistance.

Burrell et al. (2015) reported that anthracnose disease resistance was associated with a major QTL located on chromosome 5 of sorghum. Genomic studies involving a resistant genotype (SC748-5) and susceptible check (BTx623) indicated the presence of numerous amino acid changes in annotated disease resistance genes around the anthracnose QTL (Burrell et al., 2015). Resistance reactions are often exhibited as rapid death of cells in a form of hypersensitive reaction on the sorghum leaves due to vertical resistance genes (Biruma et al., 2012).

The dominant gene, $\mathrm{Cg} 1$, identified in sorghum cultivar SC748-5 contributed to $C$. sublineolum resistance (Perumal et al., 2009). Based on evaluation done using 13 advanced sorghum lines 12 lines were polymorphism for resistance to C. sublineolum associated with Cg1 (Perumal et al., 2009).

Upadhyaya et al. (2013) identified eight loci associated with anthracnose disease resistance. Disease resistance genes were observed in all the seven loci linked with SNP markers except loci 8. In addition, two QTLs were identified conditioning anthracnose resistance on linkage group (LG) 4 and LG17 related to flowering time (Phan et al., 2007).

Mohan et al. (2010) identified QTLs for anthracnose disease resistance between Xtxp95 and Plcor on SBI-06 linkage group. In addition, two QTLs were recorded between Glume T-micro and Fdnhsbml-Fdnhsbm8 of marker intervals. Anthracnose disease was controlled by a single locus located at a distal region of chromosome 5 (Cuevas et al., 2014). A study conducted using 21 elite sorghum lines under natural infection indicated the presence of anthracnose resistance associated with foliar, peduncle, rachis, grain and panicle (Marley and Ajayi 2002).

\section{Role of genomics, transcriptomics and proteomics in anthracnose resistance breeding}

Sorghum genome was sequenced by group of scientists (Paterson et al., 2009) which contribute much in molecular breeding. As compared to maize $2.3 \mathrm{Gbp}$, sorghum is relatively small genome of $730 \mathrm{Mb}$ (Paterson et al., 2009). Biruma et al. (2012) identified genes encoding resistance proteins ( $C s 1 A, C s 2 A)$, a lipid transfer protein ( $S b L T P 1)$, a zinc Wnger-like transcription factor (SbZnTF1), a rice defensinlike homolog (SbDEFL1), a cell death related protein $(S b C D L 1)$, and an unknown gene harboring a casein kinase 2like domain $(S b C K 2)$. Based on investigation done by (Li et al., 2013) genes encoding an ABA-responsive protein, a leucine-rich repeat protein, a flavonoid 30-hydroxylase and a glutathione S-transferase were induced in the resistant cultivar; however, absent in susceptible sorghum indicating the contribution for $C$. sublineolum resistance. It also observed that the accumulation of 3-deoxyanthocyanidin, luteolinidin, which is toxic to anthracnose fungus helps sorghum resistance to the disease (LO et al., 1999). In addition, co-segregation analysis indicated functional y1 gene is genetically linked with resistance to $C$. sublineolum and it was also mentioned that the accumulation of sorghum 3-deoxyanthocyanidin phytoalexins and resistance to $C$. sublineolum in sorghum require a functional y1 gene (Ibraheem et al., 2010).

\section{Inheritance of resistance to sorghum anthracnose}

Erpelding (2007) reported foliar anthracnose resistance in sorghum cultivar 'Redlan' to be controlled by a single dominant gene, while anthracnose of leaf midrib is controlled by a single recessive gene. The author observed that the two genes controlling anthracnose infection of leaf and leaf midrib are unlinked and inherited independently. Based on QTL analyses of recombinant inbred lines (RIL) a total of nine unique QTLs for anthracnose resistance were reported in a population derived from resistant parent SC155-14E and anthracnose-susceptible inbred BTx623 (Patil et al., 2017). In addition, segregating $F_{2: 3}$ progenies obtained from a cross between SC748-5 and SC414-12E, implied the presence of different sources of resistance for anthracnose.

\section{Search for anthracnose resistant sorghum genotypes}

Thomas (1995) identified a total of 16 local and improved sorghum varieties possessing resistance to foliar anthracnose disease in Mali. Marley et al. (2001a) and Marley et al. (2001b) reported unique sorghum genotypes of different maturity group (medium to late) showing resistance to foliar anthracnose. Thakur et al., (2007) identified some sorghum lines such as IS 6928 , IS 18758 , and IS 12467 as the most resistant to anthracnose through testing at various hotspot areas in India, Thailand, Ethiopia, Kenya, Zambia, Nigeria and Mali. Erpelding and Prom (2006) investigated anthracnose resistance of 22 Mozambique sorghum accessions. The authors found that 12 lines showed promising levels of resistance. Erpelding (2008) evaluated 132 sorghum landraces for foliar anthracnose and selected 109 resistant lines. Similarly, amongst 72 sorghum accessions collected from Ethiopia, Mali, Sudan, and Uganda and evaluated at Texas, seven had anthracnose resistance (Prom et al., 2011).

Singh (2014) evaluated 100 sorghum accessions and selected 10 with anthracnose resistance, while 50 had moderate resistance. Patil et al. (2017) identified the sorghum genotype 'SC155-14E' with a high level of stable resistance (nearly disease free) across several test environments.

\section{Genetic diversity assessment}

Genetic diversity is essential for plant breeders in cultivar development. Molecular markers can complement phenotypic characterization in identification of complimentary parents for breeding. Genetic diversity analysis is important to identify anthracnose resistant and genetically unrelated parents for cultivar development. Genetic diversity of sorghum has been routinely assessed using morphological traits and molecular markers. Various 
molecular markers were widely used to assess genetic diversity in sorghum such as microsatellite or SSRs (Tesfamichael et al., 2014; Amelework et al., 2015; Weerasooriya et al., 2016), RFLPs (Tao et al., 1993; Cui et al., 1995), RAPD (Nkongolo and Nsapato 2003; Uptmoor et al., 2003; Abdel-Fatah et al., 2013), AFLP (Menz et al., 2004; Geleta et al., 2006; Perumal et al., 2007) and SNPs (Mace et al., 2008) due to simplicity, reproducibility and provide high genetic information than morphological traits. In most cases morphological characters needs multiple years and locations evaluation. Expression of phenotypic traits is influenced by the genotype, environment and their interaction and crop management practices (Burow et al., 2012).

Amongst the molecular markers, microsatellites or SSRs have been widely used in genetic characterization of sorghum. Burow et al. (2012) characterized 159 sorghum landraces collected from the colder regions of China using 41 SSR markers. Authors reported that 40 out of 41 SSRs were polymorphic. Similarly, molecular diversity of 139 Kenyan sorghum was done using 11 microsatellite and high level of diversity observed (Ngugi and Onyango 2012).

Genetic characterization of Ethiopian sorghum collections were investigated by various authors using SSR markers (Adugna et al., 2013; Tadesse and Feyissa 2013; Adugna 2014; Amelework et al., 2016) and AFLP markers (Geleta et al., 2006).

Ethiopian sorghum accessions are known possessing novel traits such as better agronomic performance, variable maturity groups, high lysine, good grain quality, resistance to disease and insect pests and stay green that could be utilized in improved cultivar development (Kebede 1991).

\section{Heterosis and combing ability analyses in sorghum}

\section{Heterosis}

Heterosis is the superiority of $F_{1}$ hybrid over both of its parents (Acquaah 2009). Generally, heterosis is manifested as an increase in vigor, size, growth rate, grain yield (Feng et al., 2015), resistance to disease and insect pests, or to growing environments (Lamkey and Edwards 1999). Heterosis is estimated over the superior parent, such an estimate is sometimes referred to as heterobeltosis. Highparent heterosis is preferred in some circumstances, particularly in self-pollinated crops, when the goal is to find a better hybrid than either of the parents (Singh 1993; Poehlman and Sleper 1995; Falconer and Mackay 1996; Lamkey and Edwards 1999).

Heterosis increases yield per unit area through hybrid vigour. Therefore, heterosis breeding is one way of boosting crop productivity to supply food for the burgeoning global populations (Duvick 1999).

Both better parent and standard heterosis of sorghum was reported by several investigators for grain yield (Premalatha et al., 2006; Umakanth et al., 2006; Hariprasanna et al., 2012). Blum et al. (1990) reported significant heterosis for biomass, grain yield per plant, and grain number per panicle. Negative heterosis over the standard check also observed for days to flowering and plant height that will help to develop early maturing varieties and shorter stalks (Umakanth et al., 2006).

Epistasis is an inter-allelic gene interaction involving two or more non-allelic genes at different loci (Singh 1993). Gene interactions after genetic recombination are important sources of new and unexpected genotypes which furnish raw material for selection (Liang et al., 1972).

Physiological basis of heterosis is related to embryo, seed size and growth rates in the various stages of development. It was suggested that hybrid vigour results from larger embryo and endosperm sizes of the hybrid seeds when compared to those of the inbreds. As a result, the rate of growth in the seedling stages may be greater in the hybrids than in the inbred (Singh 1993).

\section{Combining ability effects}

Combing ability is the ability of a genotype (inbred, pure line or synthetic/composite) to transfer its desirable traits to its crosses. Combining ability studies, besides providing information on the nature of gene action, also enable classification of selected parental material with respect to breeding potential for yield and yield-related traits and disease resistance. Two types of combining ability effects are distinguished, general combining ability (GCA) and specific combining ability (SCA). The GCA helps to evaluate the contribution of an inbred line to the hybrid performance, whereas SCA is utilized to identify cross combination with superior performance (Sprague and Tatum 1942; Singh 1993; Poehlman and Sleper 1995; Acquaah 2009).

The parents with higher GCA effect will be used in recurrent selection and crosses with better SCA effect promoted to pedigree selection or backcrossing. Different selection methods proposed for recurrent selection were also considered in the context of GCA and SCA and the type of gene action contributing to the heterosis expressed in crosses (Hallauer and Miranada 1988).

In sorghum and other self-fertilizing crops selection can be practiced for additive or additive $\mathrm{x}$ additive gene effects with reasonable expectation for success in isolating the superior genotype. Selection is less effective in isolating and fixing superior genotypes due to dominance and epistasis. The dominance gene action would favour the production of hybrids; the additive gene action indicates the standard selection procedures would be effective in bringing about advantageous changes to the character. Different genetic analyses have been used extensively to obtain information about the genetic control of quantitative traits. Diallel analysis has been used most extensively by sorghum breeders to identify better parents for recurrent selection or cross for hybrid development (Pal and Prodhan 1994; Poehlman and Sleper 1995).

\section{Farmers preferences of improved sorghum technology}

In designing a sorghum variety, breeders should focus on farmers' traits of interest. In Ethiopia, several sorghum varieties were developed from exotic or landraces collected from the different sorghum growing areas in the country. However, one of the major reason why farmers have been reluctant to grow improved sorghum varieties were due to lack of farmers preferred traits (McGuire 2008).

In most sorghum technology generation and development endeavors, researchers develop the research agenda and release the new technology to farmers. However, most of the time, this technology has limited acceptance by the end users. This is due to limited involvement of the farmers in 
problem identification and the research process. Therefore, their perception and preference related to the technology are very important. Several authors reported that majority of Ethiopian farmers are growing their own low yielding local cultivars either due to limited availability of farmers preferred technology, lack of awareness or lack of appropriate technologies for their growing environments (Mulatu and Zelleke 2002; Lacy et al., 2006). In addition farmers prefer their local sorghum varieties for various purposes such as for their quality attributes for food, feed and high biomass production for fuel wood and construction material (Mekbib 2006).

Farmers' involvement in problem identification, priority setting and sorghum technology evaluation processes enables to develop client oriented varieties and new production technologies that could ultimately be easily accepted and widely adopted. The views and preferences of farmers during variety development and technology evaluation are the necessary preconditions for researchers to design and prioritize research areas. Participatory rural appraisal (PRA) is one of the multidisciplinary tools that helps to capture farmers' perception and preferences. This enhances adoption of technologies and fosters diffusion through farmer to farmer seed or technology exchange (Mulatu and Belete 2001).

Both participatory plant breeding (PPB) (Gyawali et al., 2007; Abay et al., 2008) and participatory variety selection (PVS) (Mulatu and Zelleke 2002) were reforms in technology generation and encourage better involvement of farmers. The two approaches help the farmers to be active collaborators and part of decisions (Gyawali et al., 2007).

\section{Conclusion}

Sorghum is one of important cereal crop globally and in subSaharan Africa including Ethiopia. Its production and productivity is affected by both abiotic and biotic constraints. Among the biotic factors sorghum anthracnose rank first reducing grain yield and quality. A number of investigations have been done to control anthracnose disease such as chemical control, seed treatment and residue management. However, developing sorghum anthracnose resistant varieties through resistance breeding is environmentally feasible, economical and benefits smallholder sorghum farmers. This review highlighted the status of sorghum production, important production constraints with emphasis to anthracnose disease and its control options. It also discussed sorghum genetic diversity assessment involving molecular markers; heterosis and combining ability analysis in sorghum cultivar development. The review emphasized the importance of farmers involvement in technology generation and due attention should be given by researchers on farmers preferred traits for better acceptance of sorghum technology. This review may help as valuable information for sorghum researchers focusing on breeding sorghum for anthracnose resistance and associated challenges and opportunities.

\section{Acknowledgements}

The National Research Foundation (NRF)/South Africa is sincerely thanked for financial support and the Oromia
Agricultural Research Institute for providing a study leave for the first author.

\section{References}

Abay F, Waters-Bayer A, Bjørnstad $\AA$ (2008) Farmers' seed management and innovation in varietal selection: implications for barley breeding in Tigray, Northern Ethiopia. AMBIO: A J the Hum Environ. 37 (4):312-320.

Abdel-Fatah BE, Ali EA, El-Din AAT, Hessein EM (2013) Genetic diversity among Egyptian sorghum (Sorghum bicolor L. Moench) landraces in agro-morphological traits and molecular markers. Asian J Crop Sci. 5 (2):106.

Abdi A, Bekele E, Asfaw Z, Teshome A (2002) Patterns of morphological variation of sorghum (Sorghum bicolor (L.) Moench) landraces in qualitative characters in North Shewa and South Welo, Ethiopia. Hereditas 137 (3):161172.

Acquaah G (2009) Principles of plant genetics and breeding. John Wiley \& Sons.569p.

Adugna A (2014) Analysis of in situ diversity and population structure in Ethiopian cultivated Sorghum bicolor (L.) landraces using phenotypic traits and SSR markers. SpringerPlus $3(1): 1$.

Adugna A, Snow AA, Sweeney PM, Bekele E, Mutegi E (2013) Population genetic structure of in situ wild Sorghum bicolor in its Ethiopian center of origin based on SSR markers. Genet Resour Crop Ev. 60 (4):1313-1328.

Akpa AD, Gana SD, Alabi O (1992) Foliar fungicidal spray for the control of some common foliar diseases of sorghum in Nigeria. Niger J Plant Prot. 14:92-96.

Ali MEK, Warren HL (1987) Physiological races of Colletotrichum graminicola on sorghum. Plant Dis. 71 (5):402-404. doi:10.1094/PD-71-0402.

Amelework B, Shimelis $H$, Tongoona $P$, Laing $M$, Mengistu $F$ (2015) Genetic variation in lowland sorghum (Sorghum bicolor (L.) Moench) landraces assessed by simple sequence repeats. Plant Genet Resour. 13 (02):131-14.

Amelework B, Shimelis $H$, Tongoona $P$, Laing $M$, Mengistu $F$ (2016) Genetic diversity of lowland sorghum landraces assessed by morphological and microsatellite markers. Aust J Crop Sci. 10 (3):291-298.

Ayana A, Bekele E (2000) Geographical patterns of morphological variation in sorghum (Sorghum bicolor (L.) Moench) germplasm from Ethiopia and Eritrea: quantitative characters. Euphytica 115 (2):91-104.

Berenji J, Dahlberg J (2004) Perspectives of sorghum in Europe. J Agron Crop Sci. 190 (5):332-338.

Billot C, Ramu P, Bouchet S, Chantereau J, Deu M, Gardes L, Noyer JL, Rami JF, Rivallan R, Li Y (2013) Massive sorghum collection genotyped with SSR markers to enhance use of global genetic resources. PloS one 8 (4):e59714.

Biruma M, Martin T, Fridborg I, Okori P, Dixelius C (2012) Two loci in sorghum with NB-LRR encoding genes confer resistance to Colletotrichum sublineolum. Theor Appl Genet. 124 (6):1005-1015.

Blum A, Ramaiah S, Kanemasu ET, Paulsen GM (1990) The physiology of heterosis in sorghum with respect to environmental stress. Ann Bot. 65 (2):149-158.

Boora KS, Frederiksen R, Magill C (1998) DNA-based markers for a recessive gene conferring anthracnose resistance in sorghum. Crop Sci. 38 (6):1708-1709. 
Buiate EAS, SOUZA EA, Vaillancourt L, Resende I, Klink UP (2010) Evaluation of resistance in sorghum genotypes to the causal agent of anthracnose. Crop Breed Appl Biot. 10 (2):166-172.

Burow G, Franks CD, Xin Z, Burke JJ (2012) Genetic diversity in a collection of Chinese sorghum landraces assessed by microsatellites. Am J plant sci. 3 (12):1722.

Burrell AM, Sharma A, Patil NY, Collins SD, Anderson WF, Rooney WL, Klein PE (2015) Sequencing of an anthracnoseresistant sorghum genotype and mapping of a major QTL reveal strong candidate genes for anthracnose resistance. Crop Sci. 55 (2):790-799.

CABI (2017) Sorghum anthracnose (Colletotrichum sublineolum) global distribution, Plantwise Technical Factsheet,

https://www.plantwise.org/KnowledgeBank/Datasheet.as px?dsid=14929, 2017, CAB International, Wallingford, UK. Accessed March 2018.

Casela CR, Santos FG, Ferreira AS (2001) Reaction of sorghum genotypes to the anthracnose fungus Colletotrichum graminicola. Fitopatologia Brasileira 26 (2):197-200.

Chala A, Alemu T, Prom LK, Tronsmo AM (2010) Effect of host genotypes and weather variables on the severity and temporal dynamics of sorghum anthracnose in Ethiopia. Plant Pathology J. (Faisalabad) 9 (1):39-46.

Costa RV, Zambolim L, Cota LV, Silva DD, Parreira DF, Lanza FE, Souza AGC (2015) Pathotypes of Colletotrichum sublineolum in response to sorghum populations with different levels of genetic diversity in Sete Lagoas-MG. J Phytopathol. 163 (7-8):543-553.

Craufurd PQ, Peacock JM (1993) Effect of heat and drought stress on sorghum (Sorghum bicolor). II. Grain yield. Exp Agr. 29 (01):77-86.

Crouch JA, Beirn LA (2009) Anthracnose of cereals and grasses. Fungal Divers. 39:19.

CSA (2014) Agricultural sample survey. Report on area and production of major crops, Volume I (Meher season, private peasant holding), Addis Ababa.

Cuevas HE, Prom LK, Erpelding JE (2014) Inheritance and molecular mapping of anthracnose resistance genes present in sorghum line SC112-14. Mol Breeding 34 (4):1943-1953.

Cui YX, Xu GW, Magill CW, Schertz KF, Hart GE (1995) RFLPbased assay of Sorghum bicolor (L.) Moench genetic diversity. Theor Appl Genet. 90 (6):787-796.

Dahlberg J, Berenji J, Sikora V, Latkovic D (2011) Assessing sorghum [Sorghum bicolor (L) Moench] germplasm for new traits: food, fuels \& unique uses. Maydica 56 (1750):85-92.

Davies JC (1982) Pest losses and control of damage on sorghum in developing countries-the realities and the myths.

De Wet JMJ, Huckabay JP (1967) The origin of Sorghum bicolor. II. Distribution and domestication. Evolution 21 (4):787-802.

Doggett H (1988) Sorghum. Longman Scientific \& Technical, London.

Doggett H (1991) Sorghum history in relation to Ethiopia. Plant Genetic Resources of Ethiopia:140-159.

Duvick DN (1999) Heterosis: Feeding people and protecting natural resources. The genetics and exploitation of heterosis in crops:19-29.
Ekeleme F, Kamara AY, Omoigui LO, Chikoye D, Dugje IY, Tegbaru A (2011) Effect of sowing date on striga infestation and yield of sorghum (Sorghum bicolor [L.] Moench) cultivars in the Sudan savanna of northeast Nigeria. Afr J Agr Res. 6 (14):3240-3246.

Erpelding JE (2007) Inheritance of anthracnose resistance for the sorghum cultivar redlan. Plant Pathology J. 6 (2):187190.

Erpelding JE (2008) Field evaluation of anthracnose resistance for sorghum germplasm from the Sikasso Region of Mali. Open Agr J. 2:113-120.

Erpelding JE, Prom LK (2004) Evaluation of Malian sorghum germplasm for resistance against anthracnose. Plant Pathology J. 3:65-71.

Erpelding JE, Prom LK (2006) Variation for anthracnose resistance within the sorghum germplasm collection from Mozambique, Africa. Plant Pathology J. 5 (1): 28-34.

Falconer DS, Mackay TFC (1996) Introduction to quantitative genetics. 4th edn Longman Group Ltd, Essex, UK.

FAO (2014) Database of agricultural production Food and Agriculture Organization of the United Nation, FAOSTAT. [online] Available at: http://faostat3.fao.org. Accessed July 2016.

Felderhoff T, McIntyre L, Saballos A, Vermerris W (2016) Using genotyping by sequencing to map two novel anthracnose resistance loci in Sorghum bicolor. G3: Genes | Genomes| Genetics: g3. 116.030510.

Figueiredo JEF, Depaoli HC, da Silva Coelho VT, Casela CR, da Silva Ferreira A, Guimarães CT, Gomes EA, Bressan W (2006) Genetic diversity among Colletotrichum sublineolum pathotypes isolated from sorghum (Sorghum bicolor). Rev Bras Mil. 5 (2):304-318.

Gebretsadik R, Shimelis H, Laing MD, Tongoona P, Mandefro $N$ (2014) A diagnostic appraisal of the sorghum farming system and breeding priorities in Striga infested agroecologies of Ethiopia. Agr Syst. 123:54-61.

Geleta N, Labuschagne MT, Viljoen CD (2006) Genetic diversity analysis in sorghum germplasm as estimated by AFLP, SSR and morpho-agronomical markers. Biodivers Conserv. 15 (10):3251-3265.

Gowda PSB, Frederiksen RA, Magill CW, Xu GW (1995) DNA markers for downy mildew resistance genes in sorghum. Genome 38 (4):823-826.

Gwary DM, Ali O, Gwary SD (2007) Management of sorghum smuts and anthracnose using cultivar selection and seed dressing fungicides in Maiduguri, Nigeria. Int J Agric Biol. 9 (2):326-328.

Gyawali S, Sunwar S, Subedi M, Tripathi M, Joshi KD, Witcombe JR (2007) Collaborative breeding with farmers can be effective. Field Crop Res. 101 (1):88-95.

Hallauer AR, Miranada JB (1988) Quantative genetics in maize breeding 2 nd edition lowa state Unv. Press, Ames IA, USA.

Hariprasanna K, Rajendrakumar P, Patil JV (2012) Parental selection for high heterosis in sorghum [Sorghum bicolor (L.) Moench]-Combining ability, heterosis and their interrelationships. Crop Res. 44 (3):400-408.

Harlan JR, De Wet JMJ (1972) A simplified classification of cultivated sorghum. Crop sci. 12 (2):172-176.

Harlan JR, Stemler A (1976) The races of sorghum in Africa. Origins of African plant domestication:465-478. 
Harris HB, Johnson BJ, Dobson JW, Luttrell ES (1964) Evaluation of anthracnose on grain sorghum. Crop Sci. 4 (5):460-462.

Haussmann BIG, Hess DE, Welz HG, Geiger HH (2000) Improved methodologies for breeding striga-resistant sorghums. Field Crop Res. 66 (3):195-211.

Hulluka M, Esele JPE (1992) Sorghum diseases in eastern Africa. Sorghum and millets diseases: a second world review. 502 (324):21.

Ibraheem F, Gaffoor I, Chopra S (2010) Flavonoid phytoalexin-dependent resistance to anthracnose leaf blight requires a functional yellow seed1 in Sorghum bicolor. Genetics 184 (4):915-926.

Kebede $Y$ (1991) The role of Ethiopian sorghum germplasm resources in the national breeding programme. Plant Genet Resour. :315-322.

Kumar AA, Reddy BVS, Sharma HC, Hash CT, Rao PS, Ramaiah B, Reddy PS (2011) Recent advances in sorghum genetic enhancement research at ICRISAT. Am J Plant Sci. 2 (04):589-600.

Lacy SM, Cleveland DA, Soleri D (2006) Farmer choice of sorghum varieties in southern Mali. Hum Ecol. 34 (3):331353.

Lamkey KR, Edwards JW (1999) Quantitative genetics of heterosis. The genetics and exploitation of heterosis in crops:31-48.

Li L, Zhu F, Liu H, Chu A, Lo C (2013) Isolation and expression analysis of defense-related genes in sorghumColletotrichum sublineolum interaction. Physiol Mol Plant P. 84:123-130.

Liang GH, Reddy CR, Dayton AD (1972) Heterosis, inbreeding depression, and heritability estimates in a systematic series of grain sorghum genotypes. Crop Sci. 12 (4):409411.

Lo SCC, De Verdier K, Nicholson RL (1999) Accumulation of 3deoxyanthocyanidin phytoalexins and resistance to Colletotrichum sublineolum in sorghum. Physiol Mol Plant P. 55(5):263-273.

Mace ES, Xia L, Jordan DR, Halloran K, Parh DK, Huttner E, Wenzl P, Kilian A (2008) DArT markers: diversity analyses and mapping in Sorghum bicolor. Bmc Genomics 9 (1):1.

Mann JA, Kimber CT, Miller FR (1983) origin and early cultivation of sorghums in Africa.

Marley PS, Ajayi O (2002) Assessment of anthracnose resistance (Colletotrichum graminicola) in sorghum (Sorghum bicolor) germplasm under field conditions in Nigeria. The J Agr Sci. 138 (2):201-208.

Marley PS, Diourte M, Neya A, Rattunde FW (2005) Sorghum anthracnose and sustainable management strategies in West and Central Africa. J Sustain Agr. 25 (1):43-56.

Marley PS, Elemo KA, Aba DA, Onu I, Akintayo I (2001a) Reactions of sorghum genotypes to anthracnose and grey leaf spot diseases under Sudan and Sahel Savanna field conditions of Nigeria. J Sustain Agr. 18 (2-3):105-116.

Marley PS, Thakur RP, Ajayi O (2001b) Variation among foliar isolates of Colletotrichum sublineolum of sorghum in Nigeria. Field Crop Res. 69 (2):133-142.

Mathur K, R. P. Thakur, A. Neya, P. S. Marley, C. R. Casela and L. U. Rosewich (2002) Sorghum anthracnose-problem and management strategies. In J Leslie, (ed) Sorghum and Millets Pathology 2000: Pp. 211-220.
McGuire SJ (2008) Path-dependency in plant breeding: Challenges facing participatory reforms in the Ethiopian sorghum improvement program. Agr Syst. 96 (1):139-149.

Mehta PJ, Wiltse CC, Rooney WL, Collins SD, Frederiksen RA, Hess DE, Chisi M, TeBeest DO (2005) Classification and inheritance of genetic resistance to anthracnose in sorghum. Field Crop Res. 93 (1):1-9.

Mekbib F (2006) Farmer and formal breeding of sorghum (Sorghum bicolor (L.) Moench) and the implications for integrated plant breeding. Euphytica 152 (2):163-176.

Mekbib F (2008) Genetic erosion of sorghum (Sorghum bicolor (L.) Moench) in the centre of diversity, Ethiopia. Genet Resour Crop Ev. 55 (3):351-364.

Menz MA, Klein RR, Unruh NC, Rooney WL, Klein PE, Mullet JE (2004) Genetic diversity of public inbreds of sorghum determined by mapped AFLP and SSR markers. Crop Sci. 44 (4):1236-1244.

Mohan SM, Madhusudhana R, Mathur K, Chakravarthi DVN, Rathore S, Reddy RN, Satish K, Srinivas G, Mani NS, Seetharama N (2010) Identification of quantitative trait loci associated with resistance to foliar diseases in sorghum [Sorghum bicolor (L.) Moench]. Euphytica 176 (2):199-211.

Mulatu E, Belete K (2001) Participatory varietal selection in lowland sorghum in eastern Ethiopia: impact on adoption and genetic diversity. Exp Agr. 37 (02):211-229.

Mulatu E, Zelleke H (2002) Farmers' highland maize (Zea mays L.) selection criteria: Implication for maize breeding for the Hararghe highlands of eastern Ethiopia. Euphytica 127 (1):11-30.

Neya A, Le Normand M (1998) Responses of sorghum genotypes to leaf anthracnose (Colletotrichum graminicola) under field conditions in Burkina Faso. Crop Prot. 17 (1):47-53.

Ng'uni D, Geleta M, Bryngelsson T (2011) Genetic diversity in sorghum (Sorghum bicolor (L.) Moench) accessions of Zambia as revealed by simple sequence repeats (SSR). Hereditas 148 (2):52-62.

Ngugi HK, Julian AM, King SB, Peacocke BJ (2000) Epidemiology of sorghum anthracnose (Colletotrichum sublineolum) and leaf blight (Exserohilum turcicum) in Kenya. Plant Pathol. 49 (1):129-140.

Ngugi K, Onyango CM (2012) Analysis of the molecular diversity of Kenyan sorghum germplasm using microsatellites. J Crop Sci Biotechnol. 15 (3):189-194.

Nkongolo KK, Nsapato L (2003) Genetic diversity in Sorghum bicolor (L.) Moench accessions from different ecogeographical regions in Malawi assessed with RAPD. Genet Resour Crop Ev. 50 (2):149-156.

Pal AK, Prodhan HS (1994) Combining ability analysis of grain yield and oil content along with some other attributes in maize (Zea mays L.). The Indian J Genet Plant Br. 54 (4):376-380.

Paterson AH, Bowers JE, Bruggmann R, Dubchak I, Grimwood J, Gundlach H, Haberer G, Hellsten U, Mitros T, Poliakov A (2009) The Sorghum bicolor genome and the diversification of grasses. Nature 457 (7229):551-556.

Patil NY, Klein RR, Williams CL, Collins SD, Knoll JE, Burrell AM, Anderson WF, Rooney WL, Klein PE (2017) Quantitative trait loci associated with anthracnose resistance in sorghum. Crop Sci. 57 (2):877-890.

Perumal R, Krishnaramanujam R, Menz MA, Katilé S, Dahlberg J, Magill CW, Rooney WL (2007) Genetic diversity 
among sorghum races and working groups based on AFLPS and SSRs. Crop Sci. 47 (4):1375-1383.

Perumal R, Menz MA, Mehta PJ, Katilé S, Gutierrez-Rojas LA, Klein RR, Klein PE, Prom LK, Schlueter JA, Rooney WL (2009) Molecular mapping of $C g 1$, a gene for resistance to anthracnose (Colletotrichum sublineolum) in sorghum. Euphytica 165 (3):597-606.

Phan HTT, Ellwood SR, Adhikari K, Nelson MN, Oliver RP (2007) The first genetic and comparative map of white lupin (Lupinus albus L.): identification of QTLs for anthracnose resistance and flowering time, and a locus for alkaloid content. DNA Res. 14 (2):59-70.

Poehlman JM, Sleper DA (1995) Breeding field crops. 4th lowa State University Press. Ames, USA 494p.

Premalatha N, Kumaravadivel N, Veerabadhiran P (2006) Heterosis and combining ability for grain yield and its components in sorghum [Sorghum bicolor (L.) Moench]. The Indian J Genet Plant Br. 66 (2):123-126.

Prom LK, Erpelding J, Perumal R, Isakeit T, Cuevas H (2011) Response of sorghum accessions from four African countries against Colletotrichum sublineolum, causal agent of sorghum anthracnose. Am J Plant Sci. 3 (01):125.

Repellin A, Båga M, Jauhar PP, Chibbar RN (2001) Genetic enrichment of cereal crops via alien gene transfer: new challenges. Plant Cell Tiss Org. 64 (2-3):159-183.

Resende RS, Milagres CA, Rezende D, Aucique-Perez CE, Rodrigues FÁ (2015) Bioprospecting of saprobe fungi from the Semi-Arid North-East of Brazil for the control of anthracnose on sorghum. J Phytopathol. 163 (10):787-794.

Sharma R, Upadhyaya HD, Manjunatha SV, Rao VP, Thakur RP (2012) Resistance to foliar diseases in a mini-core collection of sorghum germplasm. Plant Dis. 96 (11):16291633.

Silva DD, Costa RV, Cota LV, Figueiredo JEF, Casela CR, Lanza FE (2015) Genotype rotation for leaf anthracnose disease management in sorghum. Crop Prot. 67:145-150.

Singh BD (1993) Plant Breeding. Kalyani Pub. New Delhi, India. 896p.

Singh M, Chaudhary K, Boora KS (2006a) RAPD-based SCAR marker SCA 12 linked to recessive gene conferring resistance to anthracnose in sorghum [Sorghum bicolor (L.) Moench]. Theor Appl Genet. 114 (1):187-192.

Singh $M$, Chaudhary K, Singal HR, Magill CW, Boora KS (2006b) Identification and characterization of RAPD and SCAR markers linked to anthracnose resistance gene in sorghum [Sorghum bicolor (L.) Moench]. Euphytica 149 (12):179-187.

Singh $Y$ (2014) Screening of Sorghum germplasm for resistance to anthracnose caused by Colletotrichum graminicola. Int J Basic Appl Agric Res. 12 (1):144-146.

Smith CW, Frederiksen RA (2000) Sorghum: origin, history, technology, and production, vol 2. John Wiley \& Sons, USA.

Sprague GF, Tatum LA (1942) General vs. specific combining ability in single crosses of corn. Agron J. 34 (10):923-932.

Sun Y, Skinner D, Liang G, Hulbert S (1994) Phylogenetic analysis of Sorghum and related taxa using internal transcribed spacers of nuclear ribosomal DNA. Theor Appl Genet. 89 (1):26-32.

Tadesse H, Feyissa T (2013) Analysis of genetic diversity of Sorghum bicolor ssp. bicolor (L.) Moench using ISSR Markers. Asian J Plant Sci. 12 (2):61.
Tao Y, Manners JM, Ludlow MM, Henzell RG (1993) DNA polymorphisms in grain sorghum (Sorghum bicolor (L.) Moench). Theor Appl Genet. 86 (6):679-688.

Tari I, Laskay G, Takacs Z, Poor P (2013) Response of sorghum to abiotic stresses: a review. J Agron Crop Sci. 199 (4):264-274.

Tesfamichael TA, Githiri SM, Kasili RW, Skilton RA, Solomon $M$, Nyende AB (2014) Genetic diversity analysis of Eritrean sorghum (Sorghum bicolor (L.) Moench) germplasm using SSR markers. Mol Plant Breed. 5.

Tesso T, Perumal R, Little CR, Adeyanju A, Radwan GL, Prom LK, Magill CW (2012) Sorghum pathology and biotechnology-a fungal disease perspective: Part II. Anthracnose, stalk rot, and downy mildew. Eur J Plant Sci Biotechnol. 6 (Special Issue 1):31-44.

Thakur RP (2007) Genetic resistance to foliar anthracnose in sorghum and pathogenic variability in Colletotrichum graminicola. Indian Phytopathol. 60 (1):13-23.

Thakur RP, Mathur K (2000) Anthracnose. In: Compendium of Sorghum Diseases. (Eds. R. A. Frederiksen and G. N. Odvody). The Am Phytopathol Soc., St Paul, MN, USA, pp: 10-12.

Thomas MD (1995) Sorghum anthracnose research in West Africa: A look at the present and the future. Disease analysis through Genetics and Biotechnology: Interdisciplinary bridges to improved sorghum and millet crops lowa State University Press, Ames, lowa:127-136.

Thomas MD, Sissoko I, Sacko M (1996) Development of leaf anthracnose and its effect on yield and grain weight of sorghum in West Africa. Plant Dis. 80 (2):151-153.

Umakanth AV, Rao SS, Kuriakose SV (2006) Heterosis in landrace hybrids of post-rainy sorghum. Indian J Agr Res. 40 (2):147-150.

Upadhyaya HD, Wang YH, Sharma R, Sharma S (2013) Identification of genetic markers linked to anthracnose resistance in sorghum using association analysis. Theor appl genet. 126 (6):1649-1657.

Uptmoor R, Wenzel W, Friedt W, Donaldson G, Ayisi K, Ordon F (2003) Comparative analysis on the genetic relatedness of Sorghum bicolor accessions from Southern Africa by RAPD, AFLPs and SSRs. Theor Appl Genet. 106 (7):1316-1325.

Vavilov NI (1951) The origin, variation, immunity and breeding of cultivated plants. Translated by Chester K.S. Ronald Press, New York.366pp.

Vissoh PV, Gbèhounou G, Ahanchédé A, Kuyper TW, Röling NG (2004) Weeds as agricultural constraint to farmers in Benin: results of a diagnostic study. NJAS-Wageningen J Life Sci. 52 (3):305-329.

Weerasooriya DK, Maulana FR, Bandara AY, Tirfessa A, Ayana A, Mengistu G, Nouh K, Tesso TT (2016) Genetic diversity and population structure among sorghum (Sorghum bicolor, L.) germplasm collections from Western Ethiopia. Afr J Biotechnol. 15 (23):1147-1158.

Wortmann CS, Mamo M, Mburu C, Letayo E, Abebe G, Kayuki KC, Chisi M, Mativavarira M, Xerinda $S$, Ndacyayisenga T (2009) Atlas of Sorghum (Sorghum bicolor (L.) Moench): Production in Eastern and Southern Africa. 1-63. 